\title{
Response of Solanum melongena L. to Inoculation with Arbuscular Mycorrhizal Fungi under Low and High Phosphate Condition
}

\author{
Irfan AZIZ*, Mohd AYOOB, Paramjit Kaur JITE \\ University of Pune, Department of Botany, Pune, 411007, India ; ganai.irfan44@gmail.com ("corresponding author)
}

\begin{abstract}
Solanum melongena L. a medicinally and economically important crop plants were grown in polythene bags. The effect of mycorrhizal inoculation (Glomus mosseae) and increasing phosphate levels on the expression of the photosynthetic activity in terms of chlorophyll content. Antioxidant enzymes like peroxidase, polyphenol oxidase, root acid and alkaline phosphatase activity of Solanum melongena were evaluated. The experimental design was entirely at CRBD with eight treatments with three levels of phosphate $\left(50,100,150 \mathrm{mg} \mathrm{kg}^{-1}\right.$ of soil). Root colonization ranged from $50.33 \%$ to $67.33 \%$. The activity of the studied antioxidant enzymes were found to be increased in arbuscular mycorrhizal (AM) Solanum plants. Root phosphatase activity was greater in 100 and $150 \mathrm{mg}$ phosphate level in AM treated than non AM treated Solanum plants. Besides, only AM treated plants of Solanum reflected increase in total chlorophyll content as compared to non AM plants. This work suggests that the mycorrhiza helps Solanum plants to perform better in low and high phosphate level by enhancing antioxidant enzyme activity, acid and alkaline phosphatase activity and total chlorophyll content.
\end{abstract}

Keywords: antioxidant enzymes, chlorophyll, Glomus mosseae, root phosphatase, Solanum melongena

\section{Introduction}

The fungi that are probably most abundant in agricultural soils are arbuscular mycorrhizal (AM) fungi (Phylum Glomeromycota). The mutually beneficial relationship between feeder roots of plants and fungi is called mycorrhiza. Mycorrhizae are active living components of the soil and supply the basic enzymatic machinery for absorption, translocation and assimilating major mineral ions like phosphate and inorganic nitrogen required for symbiosis while as the plant provides the peculiar ecological niche that is necessary for fungal growth and development (Martin and Hilbert, 1991).

Phosphorous is one of the essential mineral elements that frequently limits plant growth and is taken in the form of inorganic orthophosphate $(\mathrm{Pi})$ by plants (Miyasa$\mathrm{ka}$ and Habte, 2001). Pi is the only form directly accessible to plants. Plant roots colonized with AMF hyphae can utilize source of $\mathrm{P}$ in soil that are not readily available to non AMF roots because the fungal hyphae have an enhanced ability to mineralize organic P (Joner and Johansen, 2000; Koide and Kabir, 2000; Feng et al., 2003).

Several groups of enzymes that may hydrolyze phosphorous esters are commonly called Phosphatase (Tabatabai and Bremner, 1969), which are directly involved in the acquisition of phosphorous by plants. They are present in mature arbuscules and intraradical hyphae of AM fungi (Ezawa et al., 1995). It has been shown that colonization of rape and onion by Glomus geosporum, Glomus mosseae and Glomus monosporum resulted in significant increase in root acid phosphate activity (Dodd et al., 1987). Simi- larly colonization of Carica papaya L. by Glomus mosseae showed enhanced root surface alkaline phosphatase activity by $25-114 \%$.

Thus the objectives of this study was to investigate the role of AM fungal species Glomus mosseae $(\mathrm{Gm})$ under three phosphate levels and its effect on antioxidant enzymes, phosphatase enzyme activity and total chlorophyll content in Solanum melongena L. as compared to non treated control ones.

\section{Material and methods}

\section{Plant material and experimental site}

The experiment was conducted in polythene bags $(12 \times 14 ")$ in Botany department, University of Pune, Pune - 411007. The seeds of Solanum melongena L. local variety Kantakari were obtained from Agricultural College Pune, Maharashtra, India. Seeds were germinated in sterilized soil $\left(121^{\circ} \mathrm{C}\right.$ and $103.42 \mathrm{k}$ pa pressure for $\left.1 \mathrm{~h}\right)$ garden sandy loamy soil. One month old seedlings were transplanted to pots containing $8 \mathrm{~kg}$ of autoclaved soil. Three month old, $30 \mathrm{~g}$ of Glomus mosseae containing AM colonized roots, rhizospere soil having extramatrical mycelium and spores (10-15) was taken as inoculum.

\section{Experimental design}

The experimental design consisted of Completely Randomized Block design with eight treatments having four mycorrhizal and four non mycorrhizal control ones. $\mathrm{K}_{2} \mathrm{H}$ $\mathrm{PO}_{4}$ was used as source of phosphate which was given after one month of AM inoculation and it was given weekly till 
the last observation was taken. The control plants were untreated. Plants were harvested after 60,90 and 120 days of $\mathrm{AM}$ inoculation.

\section{Rhizosphere soil analysis}

Before the beginning of experiment, soil samples were taken in order to determine the physical and chemical properties. The rhizosphere soil samples (100 gram) of garden soil used for the experiment was collected from a depth of $10-15 \mathrm{~cm}$, which was air dried at room temperature and further analyzed for the determination of $\mathrm{pH}$ ( $\mathrm{pH}$ meter), EC (conductivity meter Elico), mineral constituents like organic carbon, $\mathrm{P}_{2} \mathrm{O}_{5}, \mathrm{~K}_{2} \mathrm{O}, \mathrm{Cu}, \mathrm{Zn}, \mathrm{Mn}, \mathrm{Fe}$ (Rao, 1993), on AAS (Perkin- Elmer 3100, USA). Details of soil properties are shown in Tab. 1.

\section{AM colonization}

The percentage of AM colonization in roots was analyzed by clearing and staining of roots by Phillips and Haymans (1970) method and percent AM colonization in root was determined by Gridline intersect method Giovannetti and Mosse (1980).

\section{Antioxidant enzyme activity assay}

Enzyme extracts were prepared in extraction buffer containing $0.1 \mathrm{M}$ phosphate buffer $(\mathrm{pH} 7)$ by grinding 0.5 $\mathrm{mg}$ leaf or root sample in extraction buffer. Extracts were centrifuged at $18,000 \times \mathrm{g}$ at $5^{\circ} \mathrm{C}$ for 15 minutes (POD) and $16,000 \times \mathrm{g}$ for 10 minutes (PPO) and the supernatant was used as source of enzymes. The POD activity was assayed by Putter's (1974), method and expressed as M Kat gm $^{-1}$ fresh weight. The PPO activity was assayed by Mahadevan and Shidhar (1982), method and expressed as $\Delta$ O.D min ${ }^{-1}$ gram of fresh weight.

\section{Physiological parameter}

The total leaf chlorophyll content was measured by the method of Arnon (1949). The amount of chlorophyll present in the extract $\mathrm{mg}$ chlorophyll per gm tissue was calculated using the following equations:

mg chlorophyll g-1 tissue $=20.2(\mathrm{~A} 645)+8.029(\mathrm{~A} 663)$

$$
* \mathrm{~V} / 1000^{*} \mathrm{~W}
$$

where $\mathrm{A}=\mathrm{Absorbance}$ at specific wavelengths, $\mathrm{V}=$ final volume of chlorophyll extract in $80 \%$ acetone, $W=$ fresh weight of tissue extracted.

\section{Phosphatase activity assay}

Enzyme extracts were prepared in extraction buffer containing $50 \mathrm{mM}$ Citrate buffer ( $\mathrm{pH} \mathrm{5.3)} \mathrm{for} \mathrm{acid} \mathrm{and}$

Tab. 1. Physical and chemical soil properties of experimental site
$50 \mathrm{mM}$ Glycine $\mathrm{NaoH}$ buffer ( $\mathrm{pH}$ 10.3) for alkaline phosphatase by grinding 1 gram root samples in $10 \mathrm{~mL}$ extraction buffer. Extracts were centrifuged at $10000 \times \mathrm{g}$ for $10 \mathrm{~min}$ and the supernatant was used as source of enzyme. Phosphatase activity was determined by Lowry et al. (1954) method and was expressed in moles of PNP released $\mathrm{g}^{-1}$ fresh weight of roots.

\section{Statistical analysis}

Data were analyzed by One Way ANOVA followed by Duncan's multiple new range test (DMRT) at $p \leq 0.05$ level.

\section{Results and discussion}

As shown in Fig. 1a, after 60 days of AM inoculation, the mycorrhizal Solanum plants showed $25.00 \%$ of AM colonization, at second phosphate level the AM colonization was higher $(34.67 \%)$ than first and third level of phosphate (31.33\%, 31.67\%). After 90 days, AM colonization increased with increasing level of phosphate but after 120 days of AM inoculation at second phosphate level Solanum AM plants showed 78.33\% AM colonization which was higher than first and third level of phosphate. That means at second phosphate level, the percent of root colonization increased and at third level it was found to be inhibited. Similar results were obtained by Amijee et al. (1989), Martenson and Carlgen (1994). It is believed that a high soil phosphate level reduces both intra as well as extraradical AM development and thus inhibit AM colonization (Abbott and Robson, 1984; Liu et al., 2000).

As shown in Tab. 2 after 60 days of AM inoculation, the POD activity was higher in AM inoculated Solanum plants as compared to non mycorrhizal Solanum plants at first, second and third phosphate level. After 90 and 120 days of AM inoculation, POD activity was found to reduce in latter stages of AM colonization in all levels of phosphate. As shown in Tab. 3, PPO activity increased significantly in mycorrhizal Solanum plants than non mycorrhizal Solanum ones. PPO activity was higher in early stages of AM colonization i.e, after 60 days and later on the PPO activity was found to decline after 90 and 120 days of AM colonization in all treatments. In initial stages of AM fungal colonization, the enzyme activities were maximum but decreased in highly colonized roots. The increased activities may be due to the contribution by fungus or due to the biochemical activities as a result of infection or both. It may also be attributed to protect the plant from oxidative stresses or it may be due to the influence of AM

\begin{tabular}{cccccccccc}
\hline Physical & Depth & Sand & Silt & Clay & & & & & \\
\hline & $10-15 \mathrm{~cm}$ & $80 \%$ & $15 \%$ & $5 \%$ & & & & \\
\hline Chemical & Depth & $\mathrm{pH}$ & $\mathrm{EC}$ & OC & $\mathrm{P}_{2} \mathrm{O}_{5}$ & $\mathrm{Zn}$ & $\mathrm{Fe}$ & $\mathrm{Cu}$ & $\mathrm{Mn}$ \\
\hline & $10-15 \mathrm{~cm}$ & 7.8 & $0.1 \mathrm{mmho} / \mathrm{m}$ & $0.52 \%$ & $12 \mathrm{~kg} /$ acre & $80 \mathrm{~kg} /$ acre & $3.7 \mathrm{ppm}$ & $11.00 \mathrm{ppm}$ & $31.0 \mathrm{Ppm}$ \\
\hline
\end{tabular}

EC: electrical conductivity, OC: organic carbon, $\mathrm{P}_{2} \mathrm{O}_{5}$ : phosphorous oxide, $\mathrm{Zn}$ : zinc, $\mathrm{Fe}$ : iron, Cu: copper, Mn: manganese 
72

Tab. 2. Peroxidase activity in Solanum melongena L. inoculated with $G$. mosseae after 60, 90 and 120 days of AM inoculation

\begin{tabular}{cccc}
\hline \multicolumn{4}{c}{ Peroxidase activity } \\
\hline Treatments & 60 days & 90 days & 12 fresh weight \\
\hline $\mathrm{C}$ & $0.0121 \pm 0.0022 \mathrm{~d}$ & $0.0084 \pm 0.0001 \mathrm{~d}$ & $0.0025 \pm 0.0019 \mathrm{~d}$ \\
$\mathrm{C}+1 \mathrm{P}$ & $0.0121 \pm 0.0032 \mathrm{~d}$ & $0.0089 \pm 0.0021 \mathrm{~d}$ & $0.0032 \pm 0.0001 \mathrm{~d}$ \\
$\mathrm{C}+2 \mathrm{P}$ & $0.0130 \pm 0.0023 \mathrm{~d}$ & $0.0106 \pm 0.0002 \mathrm{~cd}$ & $0.0046 \pm 0.0001 \mathrm{~d}$ \\
$\mathrm{C}+3 \mathrm{P}$ & $0.0162 \pm 0.0020 \mathrm{~d}$ & $0.0147 \pm 0.0021 \mathrm{bc}$ & $0.0084 \pm 0.0001 \mathrm{c}$ \\
$\mathrm{Gm}$ & $0.0173 \pm 0.0000 \mathrm{~cd}$ & $0.0149 \pm 0.0021 \mathrm{~b}$ & $0.0089 \pm 0.0021 \mathrm{bc}$ \\
$\mathrm{Gm}+1 \mathrm{p}$ & $0.0202 \pm 0.0009 \mathrm{bc}$ & $0.0167 \pm 0.0030 \mathrm{~b}$ & $0.0120 \pm 0.0001 \mathrm{~b}$ \\
$\mathrm{Gm}+2 \mathrm{p}$ & $0.0214 \pm 0.0009 \mathrm{~b}$ & $0.0173 \pm 0.0001 \mathrm{bb}$ & $0.0167 \pm 0.0040 \mathrm{a}$ \\
$\mathrm{Gm}+3 \mathrm{p}$ & $0.0247 \pm 0.0036 \mathrm{a}$ & $0.0214 \pm 0.0009 \mathrm{a}$ & $0.0173 \pm 0.0004 \mathrm{a}$ \\
\hline
\end{tabular}

on the composition of amino acids and carbohydrates in host plants. Similar results are reported by Pacovsky et al. (1990) in Phaseolus vulgaris infected with $G$. etunicatum.

The chlorophyll is the essential component for photosynthesis and it increases with mycorrhizal colonization (Colla et al., 2008). The results indicated that total chlorophyll content was found to increase in mycorrhizal Solanum plants in all treatments after 60 and 90 days of AM inoculation. But after 120 days at third level of phosphate mycorrhizal Solanum plants showed slight decrease

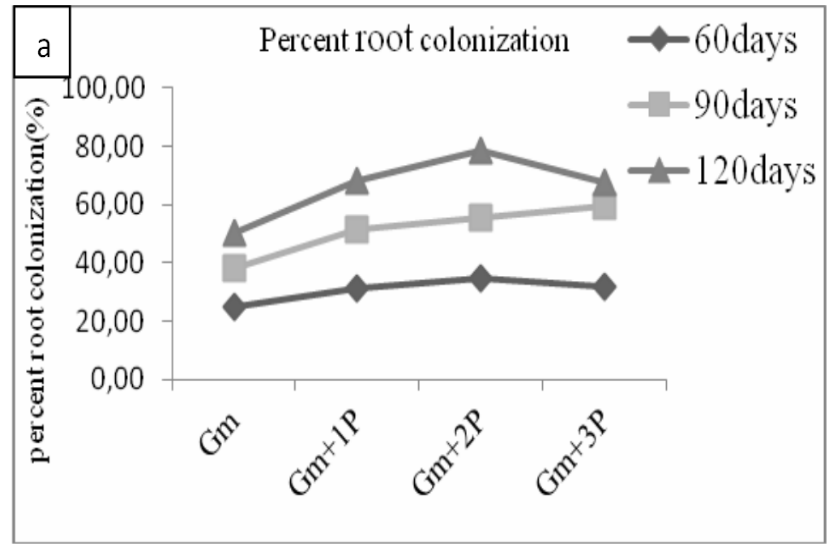

Tab. 3. Polyphenol oxidase activity in Solanum melongena L. inoculated with G. mosseae after 60, 90 and 120 days of AM inoculation

\begin{tabular}{cccc}
\hline \multicolumn{4}{c}{ Polyphenol oxidase activity $\Delta$ O.D min ${ }^{-1} \mathrm{gm}^{-1}$ fresh weight } \\
\hline Treatments & 60 days & 90 days & 120 days \\
\hline $\mathrm{C}$ & $0.668 \pm 0.289 \mathrm{~d}$ & $0.585 \pm 0.433 \mathrm{~d}$ & $0.443 \pm 0.126 \mathrm{~d}$ \\
$\mathrm{C}+\mathrm{IP}$ & $0.817 \pm 0.878 \mathrm{~cd}$ & $0.650 \pm 0.471 \mathrm{c}$ & $0.502 \pm 0.144 \mathrm{~d}$ \\
$\mathrm{C}+2 \mathrm{P}$ & $0.846 \pm 0.382 \mathrm{bc}$ & $0.679 \pm 0.520 \mathrm{c}$ & $0.585 \pm 0.433 \mathrm{~d}$ \\
$\mathrm{C}+3 \mathrm{P}$ & $0.870 \pm 0.670 \mathrm{bc}$ & $0.796 \pm 0.027 \mathrm{bc}$ & $0.650 \pm 0.471 \mathrm{c}$ \\
$\mathrm{Gm}$ & $1.276 \pm 0.804 \mathrm{abc}$ & $1.193 \pm 0.866 \mathrm{bc}$ & $0.679 \pm 0.520 \mathrm{bc}$ \\
$\mathrm{Gm}+1 \mathrm{P}$ & $1.341 \pm 0.289 \mathrm{abc}$ & $1.228 \pm 0.191 \mathrm{ab}$ & $0.776 \pm 0.577 \mathrm{ab}$ \\
$\mathrm{Gm}+2 \mathrm{P}$ & $1.556 \pm 0.382 \mathrm{ab}$ & $1.341 \pm 0.289 \mathrm{ab}$ & $0.876 \pm 0.607 \mathrm{ab}$ \\
$\mathrm{Gm}+3 \mathrm{P}$ & $1.590 \pm 0.750 \mathrm{a}$ & $1.473 \pm 0.901 \mathrm{a}$ & $0.903 \pm 0.140 \mathrm{a}$ \\
\hline
\end{tabular}

in chlorophyll content as compared to first and second phosphate level (Fig. 1b). Thus AM symbiosis enhanced the chlorophyll content of Solanum leaves which was in agreement with the results of other studies (Elahi $e t$ al., 2010; Kapoor and Bhatnagar, 2007). At first and second phosphate levels, mycorrhizal Solanum plants showed more chlorophyll content that means mycorrhization or $P$ fertilization influenced the concentration of photosynthetic pigments.

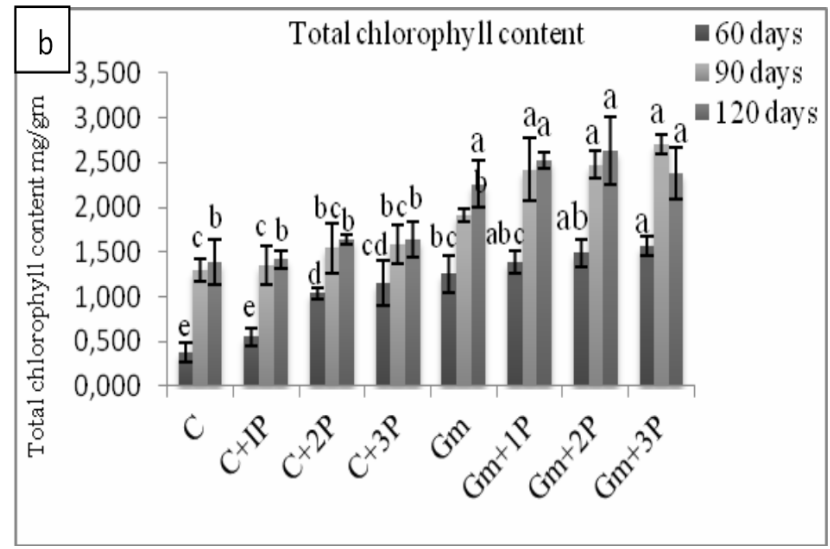

Fig. 1. Percentage of AM colonization and total chlorophyll content of Solanum melongena L. after 60, 90 and 120 days of AM treatment
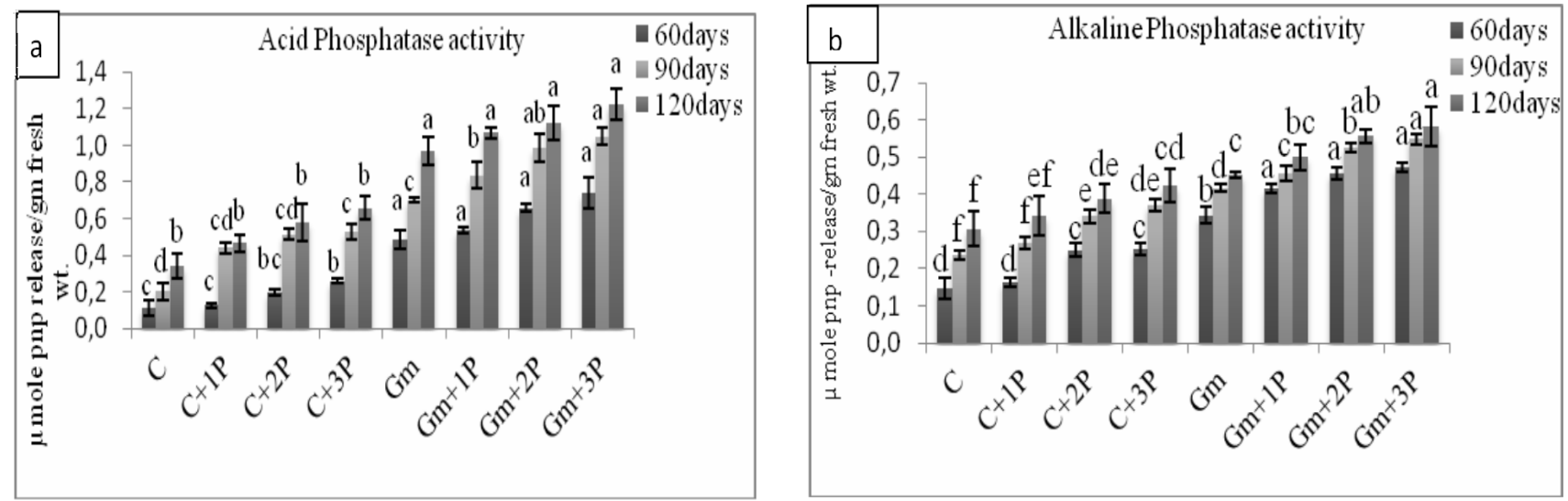

Fig. 2. Acid and alkaline phosphatase activity of Solanum melongena L. after 60, 90 and 120 days of AM treatment 
In the present experiment after 60, 90 and 120 days of AM inoculation acid and alkaline phosphatase activity increased significantly with increasing phosphate levels which led to increase in phosphate accumulation by mycorrhizal Solanum plants through intraradical mycelium as previous studies have shown that intra radical mycelium have higher proportion of phosphatase active hyphae than extraradical hyphae. Thus the study revealed the fact that mycorrhizal Solanum plants showed enhanced acid and alkaline phosphatase activities in different phosphate levels which leads to higher uptake of phosphate from soil as shown in Fig. 2a and Fig. 2b. Similar results were reported by Garcia-Gomez et al. (2002), who observed higher acid phosphatase activity in Glomus claroideum inoculated Carica papaya L. plants. In the present experiment mycorrhizal Solanum plants showed significant higher phosphatase activity at all levels of phosphate, which suggests that acid phosphatase may be associated with the growth and development of the fungus within the host tissue (Gianiazzi et al., 1979), as well as with phosphorous acquisition in the rhizosphere whereas alkaline phosphatase is closely linked to both the mycorrhizal growth stimulation and the arbuscular phase of the colonization (GianiazziPearson and Gianiazzi, 1978).

\section{Conclusions}

In conclusion, the application of AM fungi may be helpful for plant survival in moderate phosphate levels and management of mycorrhizae in field condition through proper agricultural practices could reduce fertilizer application required for most economical yield. The results of this experiment showed that AM fungi helps the Solanum plants in increment of antioxidant enzyme activities which could help the plant to protect from oxidative effects of reactive oxygen species (ROS) and protect the plants from harmful effects of stress conditions. This study also states that AM fungi help the Solanum plants by increasing photosynthetic activity and root phosphatase activity by enhancing nutrient status.

\section{Acknowledgements}

The authors are thankful to UGC New Delhi for financial support.

\section{References}

Abbott LK, Robson AD (1984) .The effect of root density, inoculum placement and infectivity of inoculum on the development of vesicular-arbuscular mycorrhiza. New Phytol 97:285-299.

Amijee F, Tinker PB, Stribley DP (1989). The development of endomycorrhizal root systems VII. A detailed study of effects of soil phosphorus on colonization. New Phytol 111:435-446.

Arnon DJ (1949). Copper enzymes in isolated chloroplasts. J
Plant and Cell Physiol 4:29-30.

Colla G, Rouphael Y, Cardarelli M, Tullio M, Rivera CM, Rea E (2008). Alleviation of salt stress by arbuscular mycorrhizal in zucchini plants grown at low and high phosphorus concentration. Biol Fertil Soils 44:501-509.

Dodd JC, Burton CC, Burns RG, Jeffries P (1987). Phosphatase activity associated with the roots and the roots and the rhizosphere of plants infected with vesicular-arbuscular mycorrhizal fungi. New Phytol 107:163-172.

Elahi FE, Mridha MAU, Aminuzzaman D (2010). Influence of AMF inoculation on growth, nutrient uptake, arsenic toxicity and chlorophyll content of eggplant grown in arsenic amended soil. Advan Natural Appl Sci 4(2):184-192.

Ezawa T, Saito M, Yoshida T (1995). Comparison of phosphatase localization in the intraradical hyphae of arbuscular mycorrhizal fungi, Glomus spp. and Gigaspora spp. Plant Soil 176:57-63.

Feng G, Song YC, Li XL, Christie P (2003). Contribution of arbuscular mycorrhizal fungi to utilization of organic sources of phosphorus by red clover in a calcareous soil. Appl Soil Ecol 22:139-148.

Garcia-Gomez R, Chaven-Espinosa J, Mejia-Chavez A, Duran BC (2002). Short term effects of Glomus claroideum and Azospirillium brasilense on growth and root acid phosphatase activity of Carcia papaya L. under phosphorous stress. Revista Latinoam Microbiol 44:31-37.

Gianiazzi S, Gianiazzi-Pearson V, Dexheimer J (1979). Enzymatic studies on the metabolism of vesicular-arbuscular mycoorhiza. III. Ultrastructural localization of acid and alkaline phosphatase in onion roots infected by Glomus mosseae (Nicol. and Gerd.). New Phytol 82:127-132.

Gianiazzi-Pearson V, Gianiazzi S (1978). Enzymatic studies on the metabolism of vesicular-arbuscular mycorrhiza. II. Soluble alkaline phosphatase specific to mycorrhizal infection in onion roots. Physiol Plant Pathol 12:45-53.

Giovannetti M, Mosse B (1980). An evaluation of techniques for measuring vesicular arbuscular mycorrhizal infection in roots. New Phytol 133: 45-57.

Joner EJ, Johansen A (2000). Phosphatase activity of external hyphae of two arbuscular mycorrhizal fungi. Mycol Res 104:81-86.

Kapoor R, Bhatnagar AK (2007). Attenuation of cadmium toxicity in mycorrhizal celery (Apium graveolens $\mathrm{L}$.). World J Microbiol Biotechnol (in press).

Koide RT, Kabir Z (2000). Extraradical hyphae of the mycorrhizal fungus Glomus intraradices can hydrolyse organic phosphate. New Phytol 148:511-517.

Liu A, Hamel C, Hamilton RI, Ma BL, Smith DL (2000). Acquition of $\mathrm{Cu}, \mathrm{Zn}$, and Fe by mycorrhizal maize (Zea mays L.) grown in soil at different $\mathrm{P}$ and micronutrient levels. Mycorrhiza 9:331-336.

Lowry OH, Robert NJ, Mei Ling WS, Crawford EJ (1954). The quantitative histochemistry of brain II enzymes 
74 measurements. J Biol Chem 207:19-37

Mahadevan A, Shridhar R (1982). Methods in physiological plant pathology. Second Edition. Sivakami Publication, Madras, p.153-155.

Martenson AN, Carlgen K (1994). Impact of phosphorus on VAM spores in two Swedish long-term field experiments. Agricult, Ecosyst Environ 47:327-334.

Martin FM, Hilbert JL (1991). Morphological, biochemical and molecular changes during ectomycorrhiza development. Experientia 47:321-331

Miyasaka SC, M Habte (2001). Plant mechanisms and mycorrhizal symbiosis to increase P uptake. Comm Soil Sci Plant Anal 32:1101-1147.

Pacovsky RS, De Silva P, Carvalho MTV, Tsai SM (1990). Increased nutrient assimilations and enzymes activities in field beans inoculated with Glomus etunicatum, Proc. Eight North American Conference on Mycorrhizae, p. 203.
Phillips JM, Hayman DS (1970). Improved procedures for clearing roots and staining parasitic and vesicular arbuscular mycorrhizal fungi for rapid assessment of colonization. Trans Br Mycol Soc 55:158-160.

Putter J (1974). Peroxidase in bergmeyer HU, ed methods of enzymatic analysis. New York, USA Academic Press, p. $567-$ 1124.

Rao AS (1993) .Analysis of soils for available major nutrients, p. 13-35. In: Tan don HLS (Ed.). Methods of analysis of soils, plants, water and fertilizers development and consultation organization, New Delhi, India.

Tabatabai MA, Bremner JM (1969). Use of p-nitrophenyl phosphate for assay of soil phosphatase activity. Soil Biol Biochem 1:301-307. 